\title{
Literacy-Based Instructional Techniques for the Middle School Mathematics Teacher
}

\author{
Nicole Parker ${ }^{1}$, Janet Breitenstein ${ }^{1} \&$ Cindy D’On Jones ${ }^{1, *}$ \\ ${ }^{1}$ Utah State University, Logan, USA \\ *Correspondence: Department of Teacher Education and Leadership, Utah State University, Logan, Utah, USA. \\ E-mail: cindy.jones@usu.edu
}

Received: February 17, 2020

Accepted: March 25, 2020 Online Published: May 20, 2020

doi:10.5430/jct.v9n2p91

URL: https://doi.org/10.5430/jct.v9n2p91

\begin{abstract}
Disciplinary literacy strategies in mathematics lessons are essential and may be embedded in three necessary parts of the lesson: before reading, during reading, and after reading. In this article, we highlight disciplinary literacy strategies that middle school mathematics teachers might implement to guide students to increased mathematical understanding and performance.
\end{abstract}

Keywords: disciplinary literacy, mathematics instruction, cross-curricular connections, middle school

\section{Introduction}

There has been much debate regarding content area/disciplinary literacy and the often-criticized notion that "every teacher a reading teacher." Fisher and Ivey (2005) argue that this approach is not working, and we need a new framework for how literacy and content can be taught symbiotically in the service of one another. Various programs have been enacted over the years, millions of dollars have been spent, and yet the challenges with reading and writing in the different disciplines still exist. Furthermore, the demands of the 21 st century require that all educators provide high-quality instruction in the disciplines to help prepare students to be successful in school and productive and contributing adults in society (Shanahan \& Shanahan, 2008).

Draper (2008) adeptly noted that disciplinary teachers are often underprepared for the literacy demands inherent in their unique disciplines, feel inadequate to teach reading and writing skills to their students, and are sometimes resistant to learning how to enact literacy strategies perhaps due to feeling pressured to get through all of the content standards. Additionally, just applying generic strategies learned in a language arts class does not suffice for the "demands of the highly specialized forms of reading and writing" that are needed to support the "required mental operations for specific math tasks" (Brozo \& Crain, 2018, p. 7). In this article, we highlight disciplinary literacy strategies that middle school mathematics teachers might implement to guide students to increased mathematical understanding and performance.

\section{Embedding Literacy Strategies}

Disciplinary literacy strategies in mathematics lessons are essential and may be embedded in three necessary parts of the lesson: before reading, during reading, and after reading. Frontloading strategies are a pre-reading scaffolding approach that prepares students by making connections from their previous knowledge to new knowledge. Guided comprehension strategies are integrated during the lessons with the intent of making deeper connections and inferences, generating questions, and possibly synthesizing new learning. Consolidating strategies can be used after reading to engage students in demonstrating their comprehension by summarizing and applying their learning through oral discussions or in writing (Buehl, 2017). Examples of these before, during, and after literacy strategies in mathematics are presented below. 


\section{Vocabulary (Frontloading Before Reading)}

Mathematics has its own vocabulary and language. Mathematics texts are often challenging as the reader has to negotiate three levels of communication, including text explanations, symbolic notations, and graphic representations (Buehl, 2017). Just as sounds are represented by letters in language arts, mathematics concepts are expressed through terms and symbols (Phillips, Bardsley, Bach, \& Gibbs-Brown, 2009). Students must understand what is being "read" in math to understand the concepts thoroughly. In addition, understanding mathematical terms can also be complicated by the various meaning of the terms in other content areas. The National Council of Teachers of Mathematics (NCTM, 2000) noted, "Students need to be able to communicate about mathematics" (Gay \& White, 2002), and to accomplish this, students need to understand the ideas.

To help students with their understanding of mathematics vocabulary, several literacy strategies may be implemented. Gay and White (2002) suggested assisting students by implementing vocabulary strategies as words are encountered as to make a better conceptual understanding. One method is "Verbal and Visual Word Association Strategies," in which the teacher provides definitions and then expands the learning by having students provide personal examples through writing and drawing. Another method is Concept Circles, which broaden knowledge by having students, make connections to the original concept. This activity involves drawing a circle and within the circle, drawing one diagonal and one vertical line to section the circle into four equal parts. A vocabulary term or phrase is placed in one of the four sections. In the other three sections, students are instructed to provide examples of similarities or differences, reflecting relationships between the four sections. The goal of Concept Circles it to connect students' prior knowledge to new mathematical ideas and terms (Rupley, Logan, \& Nichols, 1999). Both of these frontloading methods promote high-level thinking.

Another method to help students learn mathematics terminology incorporates prefixes. Many language arts classrooms teach prefixes; however, students do not always make the connection to mathematics. A ten to fifteen minute mini-lesson about prefixes such as bi, quad, penta, tri, octa, deci, di, and hexi could assist students' connection to mathematics, including lessons about polygons (Phillips et al., 2009). Such lessons assist students in using prefixes across the disciplines.

Word walls are another method for supporting mathematics vocabulary. Yates, Cuthrell, \& Rose (2011) shared the success story of one middle school's implementation of word walls. Teachers and administrators recognized the state mathematics assessment was reading-focused as the test consisted predominantly of word problems. Students needed to define, understand, and analyze the information. Teachers implemented the use of word walls for recognition, review, and retention of words and their meanings. Yates et al. (2011) noted that "state assessment scores showed an increase in the areas of reading, math ... . after students and teachers engaged in ... word walls" (p. 31).

Numerous literacy methods and strategies frontload mathematics vocabulary. Additional techniques include analogy charting, concept/definition mapping, Frayer model, mathematics reading keys, mind mapping, and student-friendly vocabulary explanations (Buehl, 2017).

\section{Think Aloud/Modeling (Guided Comprehension During Reading)}

The think-aloud is a metacognitive strategy that is commonly used in literacy instruction that mathematics teachers may also use as an effective tool to promote student understanding. As Bernadoski (2016) advised, "Using think-alouds in a math classroom allows students to stop periodically, think about their thought process, and verbalize what is happening in their minds as they read and solve word problems" (p. 5). Teachers need to model how to solve mathematics problems by using think-aloud strategies to demonstrate for students how to be mindful of their thinking and strategy behaviors. Teachers can guide students to think about their thinking by using questions such as, "What do you notice about reading when you understand what you have read? What is it that causes you difficulties?" (p.5).

Instead of assuming that middle school students read and understand the meaning of the various "overlap" words, teachers may use the think-aloud/modeling strategy to clarify the unique vocabulary of mathematics (Phillips et al. 2009). A teacher can model for students when to use stopping points for a better understanding of mathematical vocabulary. For example, when encountering overlap words such as plane, difference, radical, odd, the teacher thinks aloud, sharing various definitions of these words. 'The word plane may be used as a noun, adjective, and verb and sometimes confused with the word plain, meaning simple. The meaning of the word plane is different when it used in geometry as compared to when it is used to describe a mode of transportation or movement. In geometry, a plane is a flat, two-dimensional surface that extends infinitely far.' 
To increase effectiveness of think alouds, Ness (2018) suggests teachers incorporate questioning, inferring, synthesizing, monitoring, and clarifying into their think-alouds to help students identify when vocabulary meaning minimizes comprehension. A purposeful think-aloud may clear up confusion students have about the vocabulary used in mathematics, enabling students to concentrate on reading and understanding with precision (Phillips et al.).

The think aloud strategy will also assist students when they encounter challenging text, such as the text structure of a mathematics book or word problems. According to Phillips et al. (2009), "very few students are taught in explicit and direct ways how to read" mathematics text which is written in a succinct fashion with sidebars of information that may be difficult for proficient readers and "even more daunting for those who struggle" (p. 468). As teachers model the think-aloud process, students are encouraged to take ownership of their thinking and learning by applying the strategy to analyze where comprehension is breaking down. Talking about mathematics has the potential to demystify the various mathematics processes and empower students to improve their mathematics understanding, which in turn can build their self-efficacy as students.

\section{Writing (Consolidating Understanding After Reading)}

Current national mathematical standards include a focus on "using the language of mathematics to express mathematical ideas and communicate mathematical thinking in clear and coherent terms" (Brozo \& Crain, 2018). However, generic literacy strategies may serve to impede problem solving skills and draw students' attention away from the important cognitive thinking needed for mathematics understanding (Draper, 2008; Siebert \& Draper, 2008). Researchers emphasize the need for a different approach of using genuine disciplinary literacy strategies "to help their students think like mathematicians" (Brozo \& Crain, p. 7) and reflect the literacy experiences that organically appear in the study of mathematics.

To this end, writing should be used in mathematics lessons as "problem-solving in math begins and ends with literacy [and] it provides a concrete means for the problem solver to self-monitor, reflect, and revise" (Brozo \& Crain, 2018, p. 12). Various writing methods may be used by mathematics teachers, such as solving problems in a writing template or writing in a journal. When students transfer their thinking to writing, this "adds an additional layer of higher-order thinking" (Bernadoski, 2016, p. 5). Teachers may also have students meet in small groups to exchange their writing, ask clarifying questions, argue their mathematical thinking, and give praise and feedback to the work of others (Brozo \& Cain). Mathematics expert Burns writes, "I can no longer imagine teaching math without making writing an integral aspect of students' learning" because it "requires students to organize, clarify, and reflect on their [mathematical] ideas" (Schmoker 2011, p. 249-250). Writing in the middle school classroom needs to the rule, not the exception, as teachers will be able to use their students' writing as an influential formative assessment to gauge their understanding and growth in mathematical reasoning.

Teachers need to establish a reliable and regular routine that includes the elements of a mathematics curriculum (Schmoker, 2011) and can use the following writing ideas:

- Have students write and explain why their test answers are right or wrong to gain some credit for incorrect answers.

- Have students practice writing explanations and descriptions for mathematics concepts to deepen understanding using such prompts as "I think that the answer is ", "I think that because ", and "I came to this conclusion by

According to Cross (2009), writing in mathematics allows students to build on prior knowledge rather than simply reporting what they already know and understand. When combined with think-alouds, writing in mathematics enables students to become "active and equal participant(s)" (p. 926) in the mathematics classroom and their misconceptions and misunderstandings are revealed more clearly to their teachers. This may require some teachers, who are still clinging to the traditional teacher-centered approach, to "put the responsibility for sense-making on the students" (p. 926). When teachers use think-aloud and writing strategies during mathematics instruction, they model for students "how experts in math might actually explain, justify, and extend their understanding of problem-solving strategies" (Brozo \& Crain, 2018, p. 12).

\section{Conclusion}

Literacy is a crucial component for supporting mathematics instruction. Mathematics teachers, however, do not have to become a 'reading teacher' to incorporate literacy in their discipline. In this article, we have suggested several literacy-based instructional techniques that may be used as quick methods to support mathematics lessons. 
Implementing these simple, yet effective, methods will assist teachers in developing a more transparent comprehension of the mathematical concepts and help students foster deeper connections within the mathematics curriculum.

\section{References}

Bernadowski, C. (2016). "I can't evn get why she would make me rite in her class:" Using think-alouds in middle school math for "at risk" students. Middle School Middle, 47(4), 3-14. https://doi.org/10.1111/1467-8578.12129

Brozo, W. G., \& Crain, S. (2018). Writing in math: A Disciplinary literacy approach. Clearinghouse, 91(1), 7-13. https://doi.org/10.1080/00098655

Buehl, D. (2017). Classroom strategies for interactive learning (4th Ed.). Portsmouth, NH: Stenhouse Publishers.

Cross, D. I. (2009). Creating optimal mathematics learning environments: Combining argumentation and writing to enhance achievement. International Journal of Science and Mathematics Education, 7(5), 905-930. https://doi.org/10.1007/s10763-008-9144-9

Draper, R. J. (2008). Redefining content-area literacy teacher education: Finding my voice through collaboration. Harvard Educational Review, 78(1), 60-83. https://doi.org/10.17763/haer.78.1.k1046081431205r2

Fisher, D., \& Ivey, G. (2005). Literacy and language as learning in content-area classes: A departure from "every teacher a teacher of reading". Action in Teacher Education, 277(2), 3-11. https://doi.org/10.1080/01626620.2005.10463378

Gay, A. S., \& White, S. H. (2002). Teaching vocabulary to communicate mathematically: Success across the curriculum. Middle School Journal, 34(2), 33-38.

National Council of Teachers of Mathematics (NCTM). (2000). Principles and standards for school mathematics. Reston, VA: National Council of Teachers of Mathematics.

Ness, M. (2018). Think big with think alouds, grades K-5: A three-step planning process that develops strategic readers. Thousand Oaks, CA: Corwin.

Phillips, D. C. K., Bardsley, M. E., Bach, T., \& Gibb-Brown, K. (2009). "But I teach math!” The journey of middle school mathematics teachers and literacy coaches learning to integrate literacy strategies into the math instruction. Education, 129(3), 467-472.

Rupley, W. H., Logan, J. W., \& Nichols, W. D. (1999). Vocabulary instruction in a balanced reading program. Reading Teacher, 52(4), 336-346.

Schmoker, M. (2011). Focus: Elevating the essentials to radically improve student learning. Alexandria, VA: ASCD.

Shanahan, T., \& Shanahan, C. (2008). Teaching disciplinary literacy to adolescents: Rethinking content-area literacy. Harvard Educational Review, 1(78), 4-59. https://doi.org/10.17763/haer.78.1.v62444321p602101

Siebert, D., \& Draper, R.J. (2008). Why content-area literacy messages do not speak to mathematics teachers: A critical content analysis. Literacy Research and Instruction 47(4), 229-245. https://doi.org/10.1080/19388070802300314

Yates, P. H., Cuthrell, K., \& Rose, M. (2011). Out of the room and into the hall: Making content word walls work. The Clearing House, 84, 31-36. 